\title{
A new species of the subgenus Solskinus of the genus Antbrenus (Coleoptera: Dermestidae) from Darjeeling, India
}

\section{Новый вид кожкееда из подрода Solskinus рода Antbrenus (Coleoptera: Dermestidae) из Аарджилинга, Индия}

\section{J. Háva \\ И. Гава}

Forestry and Game Management Research Institute, Strnady 136, Praha 5 - Zbraslav CZ-252 02 Czech Republic. E-mail: jh.dermestidae@volny.cz.

Научно-исследовательский институт охотничьего хозяйства, Стрнады 136, Praha 5 - Збраслав CZ-252 02 Чехия. Nepal.

Key words: Taxonomy, new species, new records, Coleoptera, Dermestidae, Anthrenus, Solskinus, India,

Ключевые слова: таксономия, новый вид, новые находки, Coleoptera, Dermestidae, Anthrenus, Solskinus, Индия, Непал.

\begin{abstract}
The species Anthrenus (Solskinus) darjeelingi sp.n. from India, West Bengal is described, illustrated and compared with a similar species $A$. (S.) katmandui Kadej, Háva et Kitano, 2016. The new species differs in the structure of antennae and male genitalia.
\end{abstract}

Pезюме. В статье описывается новый вид Anthrenus (Solskinus) darjeelingi sp.n., близкий к $A$. (S.) katmandui Kadej, Háva et Kitano, 2016. Новый вид отличается строением усиков и гениталий самцов.

\section{Introduction}

The subgenus Solskinus Mroczkowski, 1962 of the genus Anthrenus Geoffroy, 1762 recently contains 16 species known from the Palaearctic Region [Háva, 2015, 2020; Kadej et al., 2016]. The subgenus Solskinus is characterized by a 7-antennomered antenna, with the antennal club consisting of one antennomere [Mroczkowski, 1962]. Only one species has been still known from the Himalayan Subregion. The second species is described in the present article.

\section{Material and Methods}

The size of the beetles or of their body parts can be useful in species recognition and thus, the following measurements were made:

Total length (TL) - linear distance from anterior margin of pronotum to apex of elytra.

Elytral width $(\mathrm{EW})$ - maximum linear transverse distance.

The material mentioned is deposited in (JHAC) Jiří Háva, Private Entomological Laboratory \& Collection, Únětice u Prahy, Prague-West, Czech Republic.

Specimens of the species described here are provided with red, printed labels with text as follows: «HOLOTYPE [or PARATYPE, respectively] Anthrenus (Solskinus) darjeelingi sp. nov. Jiří Háva det. 2020».

\section{Results}

\section{Anthrenus (Solskinus) katmandui Kadej, Háva et Kitano, 2016}

Material. «W-Nepal, Kali Gandaki, Khola, C.J. Rai» / «Kopchepani-Kalopani, 1500-2400 m, 16.V.84», 19 (JHAC).

Distribution. The species is described from Nepal: Kathmandu Valley; new locality data from Nepal.

Anthrenus (Solskinus) darjeelingi Háva sp. n. Figs 1-3.

Type material. Holotype $\left(\sigma^{7}\right)$ : «Indien, Darjeeling D. [West Bengal], C. J. Rai» / «Kalimpong 720 m, Lower Janake, 2.IV.1984», (JHAC). Paratype: (19): same data as holotype, (JHAC).

Description. Male. Body measurements (mm): TL 2.3 EW 1.5; body dark brown, small, oval. Dorsal surfaces covered by intermixed dark brown, yellow and white scales. Head covered only by brown scales. Palpomeres brown. Antennae consisting of 7 antennomeres, antennomeres brown, terminal antennomere very long (Fig. 1). Antennal fossa long and broad. Frons with median ocellus. Eyes with entire median margin. Pronotum covered with dark brown scales discally, intermixed with white and yellow scales on lateral margins. Scutellum triangular. Elytra with dark brown, yellow and white scales; white and yellow scales are intermixed, dark brown scales forming small spots on each elytron. Epipleuron short, with white scales. Individual scales small, triangular. Ventral surface covered with white scales, particular abdominal sternites covered only by white scales, with small, brown, lateral spots. Sternites I-V without spots in the middle, covered by white scales. Prosternum only with white scales. Metasternum only with white scales, without a large patch at lateral margins. Legs brown with white scales and white setae. Aedeagus as in (Fig. 3).

Female. Externally similar to male, but having different structure of antennae (Fig. 2).

Diagnosis. The new species closely resembles $A$. (S.) katmandui, the two species can easily reliably differentiated from each other by the structure of antennae and male genitalia. 


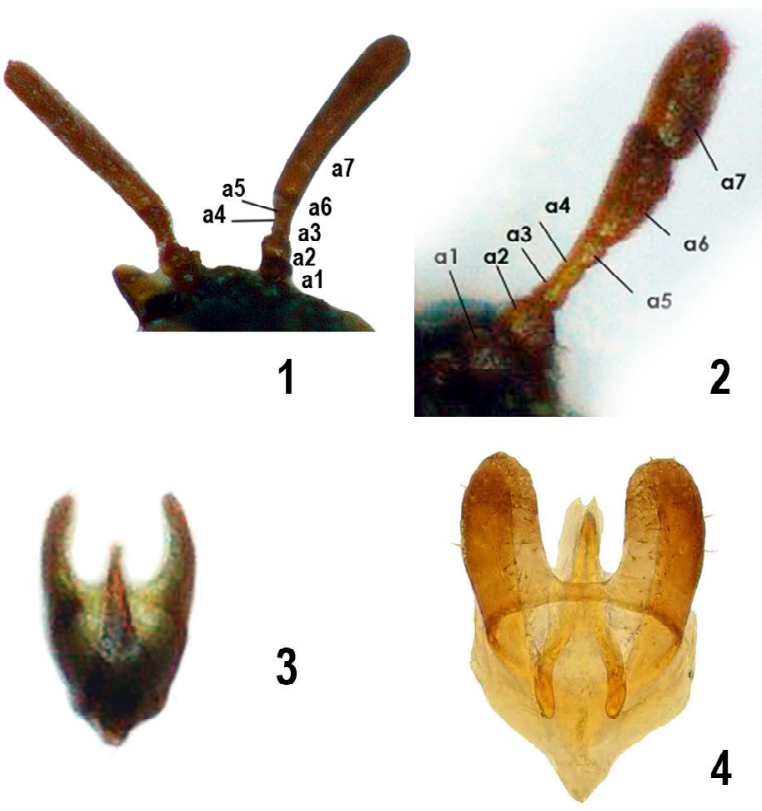

Figs 1-4. Anthrenus (Solskinus) spp. 1-3 - A. (S.) darjeelingi sp.n.: 1 - antenna of male, 2 - antennae of female, 3 male genitalia, $4-A$. (S.) katmandui, male genitalia.

Рис. 1-4. Antbrenus (Solskinus) spp. 1-3 - A. (S.) darjeelingi sp.n.: 1 - усик самца, 2 - усик самки, 3 - генитамии самџа, 4 - A. (S.) katmandui, гениталии самца.
Etymology. The epithet «darjeelingi» is derived from the place where the species was discovered - Darjeeling.

Distribution. India: Darjeeling.

\section{Acknowledgements}

I would like to thank Miloslav Rakovič (Czech Republic) for a revision of the English manuscript. The paper was supported by the Ministry of Agriculture of the Czech Republic, institutional support MZE-RO0118.

\section{References}

Háva J. 2015. World Catalogue of Insects. Vol.13. Dermestidae (Coleoptera). Leiden/Boston: Brill, xxvi +419 p.

Háva J. 2020. Dermestidae World (Coleoptera). World Wide Web electronic publication (open in 2004). http:// www.dermestidae.wz.cz (version 2018, update January 2020).

Kadej M., Háva J., Kitano T. 2016. Descriptions of three new species of Anthrenus Geoffroy, 1762 (Coleoptera: Dermestidae) with keys to the species of Anthrenus from Nepal and Taiwan // The Coleopterists Bulletin. Vol.70. No.4. P.789-796.

Mroczkowski M. 1962. Dermestidae (Coleoptera) from the Kazakh SSR // Annales Zoologici. Vol.20. P.229-259. 